\title{
Suspension of irrigation during the maturation phase of sugarcane (Saccharum spp.) cultivation
}

\author{
Salgado-García, Sergio ${ }^{1}$; Castelán-Estrada, Mepivoseth ${ }^{1 *}$; Méndez-Adorno, Jesús M. ${ }^{1}$; \\ Lagunes-Espinoza, Luz C. ${ }^{1}$; Córdova-Sánchez, Samuel ${ }^{2}$; Mendoza-Hernández, Rodolfo H. ${ }^{1}$ \\ ${ }^{1}$ Colegio de Postgraduados-Campus Tabasco, Producción Agroalimentaria Tropical-Grupo MASCAÑA. \\ Km 3.5 Periférico Carlos A. Molina S/N. H. Cárdenas, Tabasco. CP 86500. México. \\ 2 Universidad Popular de la Chontalpa. División Académica de Ciencias Básicas e Ingenierías. CA-QVyDS. \\ Carretera Cárdenas - Huimanguillo, Km 2 Cárdenas, Tabasco, México. CP 86500. \\ * Correspondence: mcastelan@colpos.mx
}

Citation: Salgado-García, S., CastelánEstrada, M., Méndez-Adorno, J. M., Lagunes-Espinoza, L. C., CórdovaSánchez, S., \& Mendoza-Hernández, R. H. (2021). Suspension of irrigation during the maturation phase of sugarcane (Saccharum spp.) cultivation. Agro Productividad. https://doi. org/10.32854/agrop.v14il1.2091

Editor in Chief: Dr. Jorge Cadena Iñiguez

Received: February 23, 2021. Accepted: October 14, 2021. Published on-line: December 1, 2021.

This work is licensed under a Creative Commons Attribution-NonCommercial 4.0 International license.

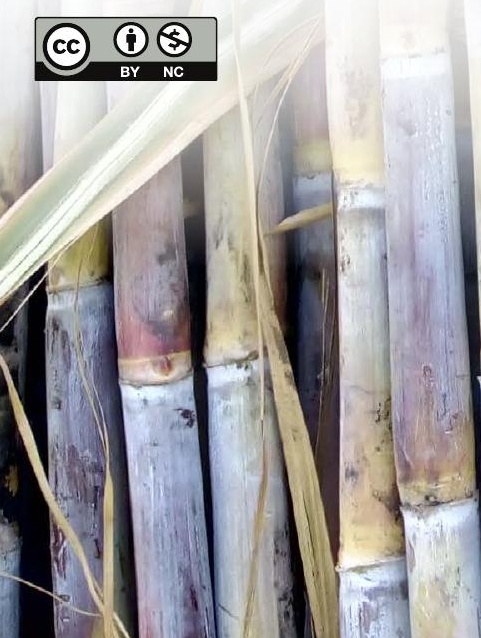

\section{ABSTRACT}

Objective: To evaluate if there is an increase in the concentration of sugars in sugarcane grinding stalks as a result of controlled water stress.

Design/Methodology/Approach: An experimental plot on cultivar MEX 69-290 was established in $2^{\text {nd }}$ ratoon cycle, on a mollic Gleysol soil in the supply area of the Pujiltic sugar mill. Five treatments in irrigation suspension were established: $\mathrm{T} 1=15$ days; $\mathrm{T} 2=30$ days; $\mathrm{T} 3=45$ days; $\mathrm{T} 4=60$ days, and $\mathrm{T} 5=75$ days of suspension. The treatments were distributed in the field in a gradient plot design, following the slope of the land, with four repetitions within each irrigation strip.

Results: The results show that suspending irrigation between 45 and 60 days before harvest increases the quality of the juices as well as the yields of the grinding stalks. In addition, natural precipitation plus irrigation water do not satisfy the water needs of the crop in the area under the scheme followed by the farmers.

Study Limitations/Implications: Irrigation rotation.

Findings/Conclusions: The authors recommend providing the necessary amount of auxiliary irrigation to satisfy the water demand of the crop during the growth cycle but suspending irrigation at the beginning of the ripening and maturity stage.

Keywords: juice quality, water stress, stalk yield, irrigation, sucrose.

\section{INTRODUCTION}

In its last fifteen harvests and within its 16,869 ha of supply surface, the Ingenio Pujiltic sugar mill has reached an average sugarcane sucrose level of $14.9 \%$ and an average yield of $101.54 \mathrm{t} \mathrm{ha}^{-1}$ of grinding stalk, currently ranking fourth at the national level (Cañeros, 2021). An average annual rainfall of 1,006 $\mathrm{mm}$ is recorded in the sugar mill's supply area; this does not satisfy the water needs of the crop, which requires around 1,500 $\mathrm{mm}$ per cycle, so producers usually apply two to three relief irrigations. A common practice is to irrigate 
up to a month before the beginning of the harvest, which turns out to be inconvenient since this last irrigation can dilute the sucrose stored in the stalk. This occurs because when the plant receives more water, it is stimulated to begin a new growth spurt and thus the quality of the juices decreases with respect to the following parameters: ${ }^{\circ}$ Brix, sucrose, humidity, reducing sugars, and purity (Salgado et al., 2012). Different studies show that continuous water stress affects the rate of water uptake, biomass accumulation, structural growth, and sucrose storage in the sugarcane stalk (Singels et al., 2010). This study was therefore conducted in order to find a water management method that achieves optimal effects. The objective of this study was to evaluate the effect of the controlled suspension of irrigation during the ripening stage on the stalk yield and juice quality of the MEX 69-290 cultivar, cultivated on a mollic Gleysol soil.

\section{MATERIALS AND METHODS}

The study area. Located in the supply area of the Ingenio Pujiltic sugar mill, along coordinates UTM $561817 \mathrm{X}-1801347 \mathrm{Y}$ on km 46+000 of the Tuxtla GutiérrezVenustiano Carranza federal highway in Chiapas, at an altitude of $625 \mathrm{~m}$ above sea level. The climate is subhumid warm with summer rains with an average annual temperature of $25^{\circ} \mathrm{C}$ and average annual rainfall of 1,006 mm (CONAGUA, 2012). The soil where the experiment was established is a mollic Gleysol cultivated with the MEX 69-290 variety, second ratoon crop (Salgado et al., 2008).

Treatments and experimental design. Five irrigation suspension treatments were tested with four repetitions during the last 75 days of the crop's maturation phase (Figure 1). Each treatment received several irrigations throughout the growth cycle, initiating suspension on the scheduled dates: $\mathrm{T} 1$ suspension at 15 days, T2 suspension at 30 days, T3 suspension at 45 days, T4 suspension at 60 days, and T5 suspension at 75 days before harvest.

Agronomic management. The following were conducted: reseeding, cultivation with hooks, manual and chemical weed control, and fertilization at a dose of 140N-80P-120 NPK at 75 days, using triple $17+$ urea $+\mathrm{KCl}$ as sources (Salgado et al., 2008).

Soil water content. It was determined by the gravimetric method (NOM-2000). Sampling began on 11/15/2011 using a stainless steel auger. Three preliminary samples

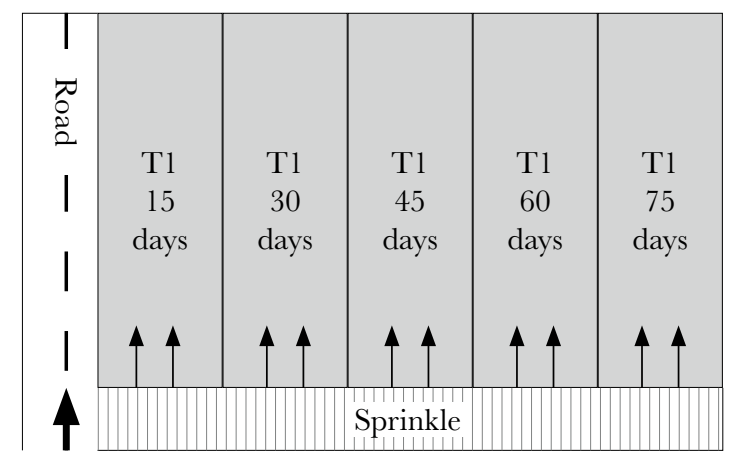

Figure 1. Distribution of Irrigation Suspension Treatments in sugar cane at Pujiltic sugar mill. The water in the plots runs through the sprinkle, from the left to the right. 
were taken from a depth of 0 to $30 \mathrm{~cm}$ and 30 to $60 \mathrm{~cm}$, with three repetitions in each plot. At the beginning of the treatments, the samples were taken from 0 to $30 \mathrm{~cm}$ for each treatment, with three repetitions. The wet weight was recorded in the field with a semi-analytical scale and the samples were taken to the LASPA laboratory at the Tabasco Campus where they were dried in an oven at $105^{\circ} \mathrm{C}$ for $24 \mathrm{~h}$ for subsequent analysis.

Water retention curves. The soil samples were dried at room temperature, ground, sieved at $0.5 \mathrm{~mm}$, and then taken to the Soil Physics Laboratory of Colegio de Postgraduados (Montecillo Campus) to calculate their moisture retention curves and to determine the soil moisture constants: moisture at field capacity $(\mathrm{FC}=1 / 3 \mathrm{~atm})$, critical moisture $(\mathrm{CM}=5$ atm), and permanent wilting point ( $\mathrm{PWP}=15 \mathrm{~atm})$.

Irrigation depth. The amount of water applied to the crop was determined based on the rainfall recorded by the Ingenio Pujiltic weather station, added to the water applied through surface irrigation, which was calculated using a triangular pourer. The flow rate was calculated according to the experimental formula developed by King (1962):

$$
Q=C * H * 2.47
$$

where: $Q=$ flow rate $(\mathrm{L} / \mathrm{s}), C=$ experimental coefficient (constant value for right angles $=$ 1.34), $H=$ head height (m).

The irrigation depth was calculated with the following formula:

$$
\operatorname{Lr}=(Q * t) / S
$$

where: $L r=$ irrigation depth, $Q=$ flow rate $(\mathrm{L} / \mathrm{s}), t=$ time $(\mathrm{h}), S=$ surface (ha).

Experimental yield. In each treatment, 10 linear m were measured in two furrows and the number of stalks per primary shoot was counted. In each row, five complete stalks were randomly sampled and their total weight was recorded, followed immediately by the weight of the grinding stalk. These data were used to calculate the biomass yield as well as the grinding stalk yield $\left(\mathrm{t} \mathrm{ha}^{-1}\right)$.

Climatological data. The evaporation data $(\mathrm{mm})$, minimum and maximum temperatures $\left({ }^{\circ} \mathrm{C}\right)$, and precipitation data $(\mathrm{mm})$ were taken from the records of the automated weather station of the Ingenio Pujiltic mill. The irrigation requirement was determined using the method by Blaney and Criddle (1950) and the irrigation requirement schedule was subsequently developed.

Maturity control. A record of the degrees Brix was made every 15 days starting at 9.5 months of the crop's growth. The juice samples were taken in the middle part of the stalk using a stainless steel punch. In each treatment, a ${ }^{\circ}$ Brix reading was made with five repetitions using an ATAGO $^{\circledR}$ brand manual refractometer.

Juice quality. It comprises degrees Brix, sucrose, moisture, reducing sugars, and purity. The juice sampling was carried out three days before harvest in 10 stalks per treatment, 
with four repetitions. The quality of the juices was determined in the Ingenio Pujiltic laboratory using the method of Section 8-10.

Statistical analysis. The data were analyzed using a completely randomized design and Tukey's multiple comparison $(\mathrm{p} \leq 0.05)$ was used with the SAS software.

\section{RESULTS AND DISGUSSION}

Water balance. The plot was scheduled to be harvested on April 25, 2012. During its growth cycle, it received 1,049 $\mathrm{mm}$ of rainfall (Table 1), $219.0 \mathrm{~mm}$ of water from three supplementary irrigations during the months of November to January (Table 2), and had 20.11 to $40.60 \mathrm{~mm}$ of surface water depth on average in the suspended irrigation treatments. The total sum of irrigation and precipitation fluctuates between $1,288.11$, and $1,308.60 \mathrm{~mm}$ depending on the suspended irrigation treatments (Table 2 ), which does not satisfy the $1,500 \mathrm{~mm}$ water requirement that sugarcane needs for normal growth; the Blaney and Criddle (1950) method estimates a 1,303.6 mm water requirement for this plot.

The irrigations applied on the months of June, August, and September exceed the water needs of the crop (Table 1), which is why the crop was stressed by excess water during the growth stage. In contrast, irrigation is required during the months of October to February to prevent the crop from being stressed by drought. To increase water efficiency, 8 irrigations should be applied during this period with a surface depth of $40.0 \mathrm{~mm}$ each, which means watering every 18 days. In this way, water would be retained by the soil and absorbed better by the crop.

The rainy season took place from May to October 2011 and accumulated a total of 880 $\mathrm{mm}$; in this period, the Blaney and Criddle (1950) method indicates an excess of water for the crop (Table 1). However, from November to December 2011, it rained $24.3 \mathrm{~mm}$, which is insufficient and affects the final stage of sugarcane growth, therefore making it necessary to apply supplementary irrigation (Salgado et al., 2003). Figure 2 shows the water content data at FG (50.7\%), CM (31.2\%), and PWP (25\%). This soil retains $19.5 \%$ of usable water.

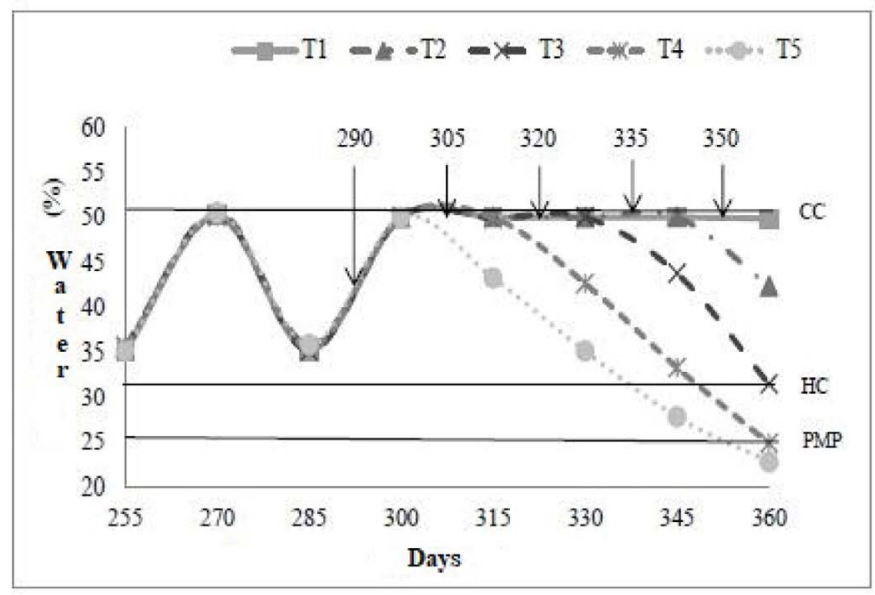

Figure 2. Content of water (\%) in the soil cultivated with the MEX 69-290 cv., in a molic Gleysol during the growth stage. Plot of Mr. Hipólito Pedrero Alegría at Pujiltic sugar mill, Chiapas, Mexico. 


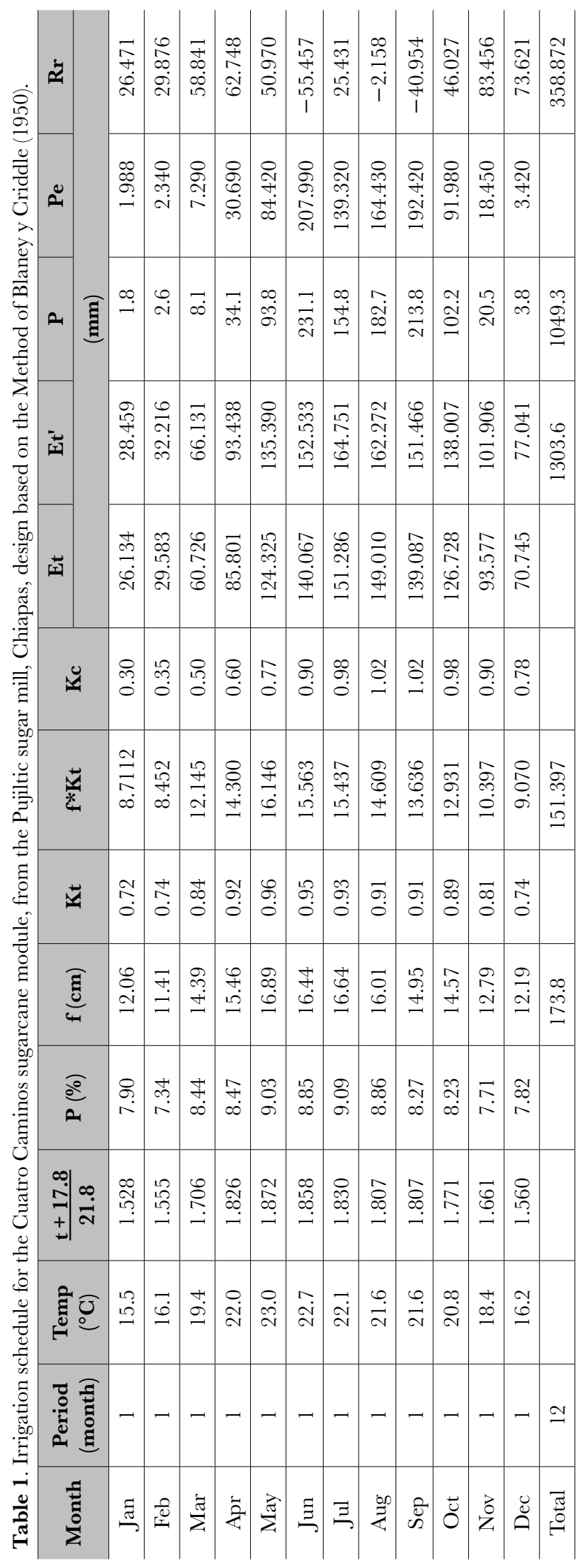


Soil moisture data starting at 255 days indicate an increase in soil moisture above FG due to the last application of supplementary irrigation.

Effect on degrees Brix and soil moisture. Irrigation suspension and the corresponding measurements of soil moisture began 290 days after sprouting (Table 4 and Figure 4). T5 started at 290 days when the soil moisture was between FC and CM. In this treatment, $23^{\circ}$ Brix were recorded in the stalk, the ripening and maturing process was interrupted, and it was observed that the crop matured slowly, reaching $24^{\circ}$ Brix at 335 days (Figure 3), affected by the decrease in water content to CM as reported by Inman-Bamber et al. (2012). Since the water content decreased to PWP, $25^{\circ}$ Brix were recorded at the time of harvest. Before harvesting, water stress was observed in the plant as well as small cracks in the soil. It is not advisable to suspend irrigation 75 days before harvest.

T4 began at 305 days, when the soil still had excess moisture; FG was reached at 317 days. This excess in moisture lasting 15 days interrupted the maturation process (Figure 3). As the soil moisture decreased to PWP, the MEX 69-290 cultivar showed signs of a water deficit that affected the ripening and maturing process (Salgado et al., 2012), reaching 24.5 ${ }^{\circ}$ Brix at harvest. Mollic Gleysol soil can maintain moisture between FG and CM from one irrigation during 32 days in early March, and for 30 days after mid-March, so watering every 15 days was detrimental to the crop.

T3 was applied at 320 days when the moisture content was higher than FC. After 335 days, the soil moisture decreased until reaching $\mathrm{CM}$ at the time of harvest. Due to the high soil moisture, the ripening and maturing process was interrupted (Singels et al., 2010) reaching only $23^{\circ}$ Brix at the time of harvest (Figure 3 ).

T2 was applied at 335 days, with accumulated moisture from previous irrigations higher than FC. After 350 days, soil moisture began to decrease, staying close to FC at harvest time. Excess water content interrupted the ripening and maturing of the MEX 69290 cultivar (Taiz and Zeiger, 2004), achieving only $22^{\circ}$ Brix at time of harvest (Figure 3). T1 was applied at 350 days, but the soil maintained moisture above FC due to the previous irrigations, which caused the stalks to not ripen (Pimentel, 2004; Taiz and Zeiger, 2004), reaching only $23^{\circ}$ Brix at the time of harvest (Figure 3 ). This was moderately favored by an increase in temperature in the month of April (Table 1).

Table 2. Water balance in sugarcane cultivation in a plot in the supply area of Pujiltic sugar mill, Chiapas.

\begin{tabular}{|c|c|c|c|c|c|c|c|}
\hline $\begin{array}{c}\text { Phenologic } \\
\text { stage }\end{array}$ & $\begin{array}{c}\text { Irrigation } \\
\text { Dates }\end{array}$ & $\begin{array}{c}\text { Time } \\
(\mathbf{h})\end{array}$ & $\begin{array}{c}\text { Water } \\
\text { spending } \\
(\mathrm{L} / \mathrm{s})\end{array}$ & $\begin{array}{c}\text { Irrigation } \\
\text { sheet }(\mathbf{m m})\end{array}$ & $\begin{array}{c}\text { Total sheet } \\
(\mathbf{m m})\end{array}$ & $\begin{array}{c}\text { Irrigation } \\
\text { requirement } \\
(\mathbf{m m})\end{array}$ & $\begin{array}{c}\text { Deficit }(-) \text { or } \\
\text { Excess }(+)\end{array}$ \\
\hline \multirow{3}{*}{ Growth } & $10 / 11 / 2011$ & 24 & 43.65 & 75.43 & & 83.46 & +8.03 \\
\hline & $10 / 12 / 2011$ & 24 & 39.46 & 68.19 & 219.05 & 73.62 & +5.43 \\
\hline & $10 / 01 / 2012$ & 24 & 43.65 & 75.43 & & 26.47 & -48.96 \\
\hline \multirow{5}{*}{$\begin{array}{l}\text { Seasoning and } \\
\text { Maturity }\end{array}$} & $11 / 02 / 2012$ & 9 & 52.66 & 20.11 & 20.11 & 26.46 & +6.35 \\
\hline & $26 / 02 / 2012$ & 10 & 19.20 & 11.35 & 31.46 & 26.46 & -5.00 \\
\hline & $12 / 03 / 2012$ & 9 & 31.76 & 16.81 & 36.92 & 51.85 & +14.93 \\
\hline & $27 / 03 / 2012$ & 12 & 22.15 & 15.64 & 35.75 & 51.85 & +16.10 \\
\hline & $11 / 04 / 2012$ & 8 & 43.55 & 20.49 & 40.60 & 52.88 & +12.28 \\
\hline
\end{tabular}




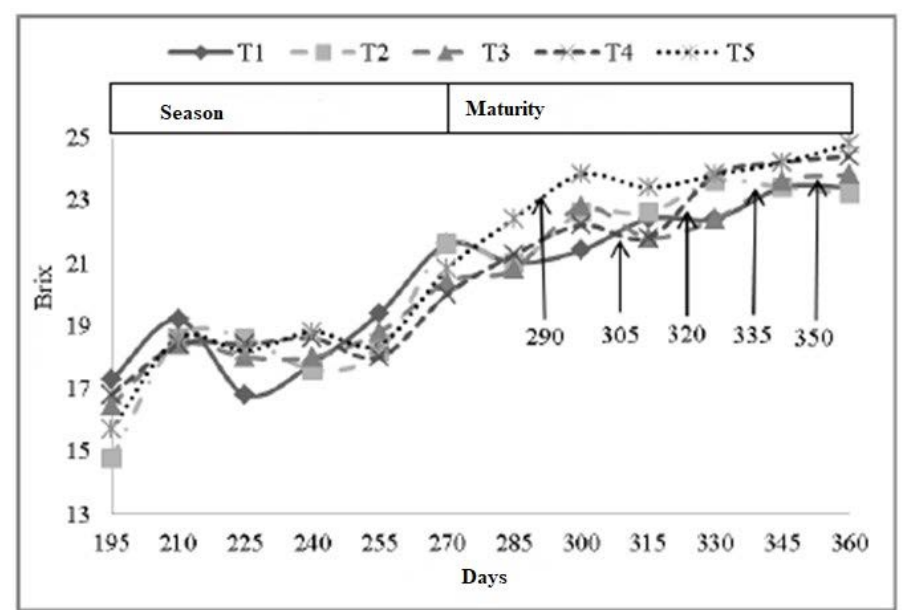

Figure 3. Evolution of Brix on cv. MEX 69-290 grown in a plot on a Gleysol molic soil, at Pujiltic sugar mil, Chiapas.

Effect on juice quality and yield of the grinding stalk. The effects on the juice quality and yields of the MEX 69-290 cultivar are presented in Table 3. No significant differences were observed for degrees Brix, sucrose, moisture, fiber, or cane yield. Due to the impact that some of these variables have on the price of sugarcane, an interpretation of the observed trends has been put forth.

T5 suspended irrigation at 75 days before harvest and presented a maturity index of 6.9 , indicative that the cane is ripe with reducing sugars close to zero. Purity was high and the juice sucrose content was $12.8 \%$ with $13.2^{\circ} \mathrm{Brix}$, which are considered low compared to other treatments. The estimated yield was $109 \mathrm{t} \mathrm{ha}^{-1}$ (Table 3). This could be due to excess water stress when suspending the water supply 75 days before harvest and due to stress from excess water during the growth stage (Viator et al., 2012); therefore, suspending water for 75 days is not recommended for the Ingenio Pujiltic area.

T4 suspended irrigation at 60 days before harvest and showed a maturity index of 7 with reducers close to zero (Table 3); the previous irrigation possibly caused this value

Table 3. Juice quality and yield of sugarcane mill stem under controlled water stress treatments at the Pujiltic sugar mill, Chiapas.

\begin{tabular}{l|c|c|c|c|c|c|c|c|c}
\hline $\begin{array}{c}\text { Treat. days } \\
\text { without } \\
\text { irrigation }\end{array}$ & $\begin{array}{c}\text { Weight } \\
(\mathbf{k g})\end{array}$ & Brix & $\begin{array}{c}\text { Saccharose } \\
(\%)\end{array}$ & $\begin{array}{c}\text { Purity } \\
(\%)\end{array}$ & $\begin{array}{c}\text { Humidity } \\
(\%)\end{array}$ & $\begin{array}{c}\text { Reducing } \\
\text { sugars } \\
(\%)\end{array}$ & $\begin{array}{c}\text { Fiber }(\%) \\
\text { (\%) }\end{array}$ & $\begin{array}{c}\text { Maturity } \\
\text { index }\end{array}$ & $\begin{array}{c}\text { Yield } \\
(\mathbf{t} / \mathbf{h a})\end{array}$ \\
\hline $1(15)$ & $12.95 \mathrm{a}$ & $15.15 \mathrm{a}$ & $12.86 \mathrm{a}$ & $85.06 \mathrm{a}$ & $70.28 \mathrm{a}$ & $0.32 \mathrm{a}$ & $11.80 \mathrm{a}$ & $5.98 \mathrm{a}$ & $112.06 \mathrm{a}$ \\
\hline $2(30)$ & $11.05 \mathrm{a}$ & $14.81 \mathrm{a}$ & $13.03 \mathrm{a}$ & $88.14 \mathrm{a}$ & $69.78 \mathrm{a}$ & $0.22 \mathrm{a}$ & $11.95 \mathrm{a}$ & $8.45 \mathrm{a}$ & $109.11 \mathrm{a}$ \\
\hline $3(45)$ & $12.33 \mathrm{a}$ & $15.92 \mathrm{a}$ & $13.20 \mathrm{a}$ & $88.03 \mathrm{a}$ & $70.05 \mathrm{a}$ & $0.22 \mathrm{a}$ & $12.27 \mathrm{a}$ & $8.65 \mathrm{a}$ & $125.99 \mathrm{a}$ \\
\hline $4(60)$ & $12.65 \mathrm{a}$ & $15.66 \mathrm{a}$ & $12.90 \mathrm{a}$ & $83.57 \mathrm{a}$ & $71.02 \mathrm{a}$ & $0.25 \mathrm{a}$ & $12.76 \mathrm{a}$ & $7.38 \mathrm{a}$ & $123.79 \mathrm{a}$ \\
\hline $5(75)$ & $11.75 \mathrm{a}$ & $14.81 \mathrm{a}$ & $12.81 \mathrm{a}$ & $86.58 \mathrm{a}$ & $70.08 \mathrm{a}$ & $0.28 \mathrm{a}$ & $11.31 \mathrm{a}$ & $6.94 \mathrm{a}$ & $109.73 \mathrm{a}$ \\
\hline Average & 12.15 & 15.26 & 12.95 & 85.27 & 70.23 & 0.26 & 12.01 & 7.47 & 116.12 \\
\hline G.V. $(\%)$ & 10.61 & 8.18 & 6.60 & 5.47 & 1.43 & 21.28 & 7.04 & 20.07 & 15.04 \\
\hline F Prob. & 0.29 & 0.63 & 0.96 & 0.53 & 0.50 & 0.12 & 0.23 & 0.13 & 0.51 \\
\hline MSD & 2.90 & 2.82 & 1.93 & 10.52 & 2.27 & 0.12 & 1.91 & 3.38 & 39.37 \\
\hline
\end{tabular}


to be less than T3. Purity was high, however, with juice sucrose of $12.9 \%$ and $15.7^{\circ}$ Brix. The crop did not show water stress and the loss of soil moisture was beneficial for the accumulation of sucrose (McCormick et al., 2008). The stalk yield was $123 \mathrm{t} \mathrm{ha}^{-1}$, higher than the T5 yield. Cane yield in T4 could be increased if it is drained every 18 furrows to avoid excess moisture during the growth stage. In addition, the water need of the crop must be satisfied (Singels et al., 2010) since the required volume of water is not provided $(1,500 \mathrm{~mm})$, although the irrigation depth must be smaller. The sugarcane crop should only be watered in the growth stage followed by suspended irrigation for the crop to ripen and mature.

In T3, irrigation was suspended 45 days before harvest, reached a maturity index of 8 , and showed the highest quality among the treatments despite the effect of the previous irrigations that reduced the degrees Brix (Table 3). The warm temperatures of March and April (Table 1) and the soil with CM favored ripening and maturing (Inman-Bamber et al., 2012), resulting in the yield of $125 \mathrm{tha}^{-1}$ that turned out to be the highest. The irrigation program aplied in Cuatro Caminos area should be reviewed to adjust the irrigation volume, interval, and depth, in addition to surface drainage (Silva et al., 2008). Irrigation at up to 45 days before harvest is recommended for this area of Ingenio Pujiltic.

In T2, irrigation was suspended 30 days before harvest, obtaining a maturity index of 8 , and the sugarcane was considered mature with reducers close to zero. The excess of soil moisture in the final stage of maturation of the MEX 69-290 cultivar induced new growth (Lingle et al., 2010), and although it is not reflected in the juice quality, it is manifested in the decrease in yield to $109 \mathrm{t} \mathrm{ha}^{-1}$ with regard to T4 and T3. For this reason, it is not advisable to water 30 days before harvest in this area of Ingenio Pujiltic.

T1 suspended irrigation 15 days before harvest, presented the lowest maturity index with 5, high purity, $12.9 \%$ juice sucrose, and $15.2{ }^{\circ}$ Brix. The experimental yield was 112 $\mathrm{t} \mathrm{ha}^{-1}$. Excess rainfall during the growing season and the lack of a drainage system were limitations to achieving higher yield and quality of sugarcane juice (Lingle et al., 2010). To achieve increases in sugarcane yields, it is necessary to establish a surface drainage system with drains every 18 furrows. It is not advisable to water 15 days before harvest because the moist soil makes the tasks difficult, in addition to the undesirable effects on ripening and maturation.

\section{GONGLUSIONS}

Using the method by Blaney and Criddle (1950), the irrigation requirement for the Cuatro Caminos module of the Ingenio Pujiltic sugar mill was estimated at 1,303.6 mm, a value that is lower than the $1,500 \mathrm{~mm}$ requirement generally established for the cultivation of sugarcane; natural precipitation plus irrigation water does not satisfy the water needs of the crop. Therefore, the authors recommend providing the necessary supplementary irrigations to satisfy the water needs of the sugarcane crop according to the irrigation schedule. In addition, the authors recommend establishing a surface drainage system and suspending irrigation between 45 and 60 days before harvest to increase the yield of the grinding stalk and to improve the quality of sugarcane juices. 


\section{AKNOWLEDGEMENTS}

The authors thank the Produce Chiapas, A.C. foundation, the sugarcane producers, and the Ingenio Pujiltic sugar mill for the financial support and support to carry out this work.

\section{REFERENGES}

Blaney, H. F., \& Criddle, W. D. 1950. Determining Water Requirements in Irrigated Areas from Climatological Irrigation Data. Technical Paper No. 96, US Department of Agriculture, Soil Conservation Service, Washington, D.C. 48 p.

Cañeros. 2021. Boletín técnico de la Unión Nacional de Cañeros A.C.- GNPR: Info-zafra 2020-2021. www. caneros.org.mx. Fecha de consulta 24/06/2021.

CONAGUA. 2012. Normales climatológicas por estado. https://smn.conagua.gob.mx/es/informacionclimatologica-por-estado?estado=chis. Fecha de consulta 15/08/2012.

Inman-Bamber, N.G., Lakshmanan, P., \& Park, S. 2012. Sugarcane for water-limited environments: Theoretical assessment of suitable traits. Field Crops Research, 134: 95-104.

King, W. H. 1962. Manual de hidráulica, para la resolución de problemas de hidráulica. Unión Tipográfica Editorial Hispano-Americana. México. 536 p.

Lingle, S. E., Johnson, R. M., Tew, T. L., \& Viator, R. P. 2010. Changes in juice quality and sugarcane yield with recurrent selection for sucrose. Field Crops Research, 118: 152-157.

McCormick, A. J., Cramer, M. D., \& Watt, D. A. 2008. Culm sucrose accumulation promotes physiological decline of mature leaves in ripening sugarcane. Field Crops Research, 108: 250-258.

NOM.2000. Que establece las especificaciones de fertilidad, salinidad y clasificación de suelos. Estudios, muestreo y análisis. NOM-021-RECNAT. DOF. 85 p.

Pimentel, C. 2004. La relación de la planta con el agua. Seropédica: Ed. 191 p.

Salgado G. S., D. J. Palma-López, J. Zavala-Cruz, L. C. Lagunes-Espinoza., M. Castelán-Estrada., G. F. Ortiz-García., J. F. Juárez-López., J. A. Rincón-Ramírez y E. Hernández-Nataren. 2008. Programa sustentable de fertilización para el ingenio Pujiltic, Chiapas, México. Terra-Latinoamericana, 26(4): 361-373.

Salgado, G. S., Núñez, E. R., Peña, C. J. J., Etchevers, B. J. D., Palma, L. D. J. \& Soto, H. M. R. 2003. Manejo de la fertilización en el rendimiento, calidad del jugo y actividad de invertasas en caña de azúcar. Interciencia, 28(10): 476-480.

Salgado, G.S., Lagunes, E. L.C., Ortiz, G. C. F., Bucio, A. L., \& Aranda, I. E. M. 2012. Caña de azúcar: producción sustentable. Colegio de Postgraduados-Mundi Prensa. México. 493 p.

Silva, M. A, Silva, J. A. G., Enciso, J., Sharma V., \& Jifon, J. 2008. Yield components as indicators of drought tolerance of sugarcane. Sci. Agric., 65: 620-627.

Singels, A. M., van den Berg, Smit, M. A., Jones, M. R., \& van Antwerpen, R. 2010. Modelling water uptake, growth and sucrose accumulation of sugarcane subjected to water stress. Field Crops Research, 117: 59-69.

Taiz, L.; Zeiger, E. 2004. Fisiología Vegetal. 3. ed. Porto Alegre: Artmed. 719 p.

Viator, R. P., White Jr. P.M., Hale, A. J., \& Waguespack, H.L. 2012. Screening for tolerance to periodic flooding for cane grown for sucrose and bioenergy. Biomass and Bioenergy, 44: 56-63. 